\title{
A Research on the Construction Thought of Applied Financial Discipline System in the Internet Finance Era
}

\author{
Lisha Ma \\ Yunnan University Of Bussiness Management, Kunming City, Yunnan \\ Province, 650106, China
}

\begin{abstract}
The rapid development of Internet finance has a great impact on the construction of applied financial discipline system. However, many colleges and universities do not realize this and they still adopt the traditional teaching methods in the financial professional teaching, which results in poor teaching quality. Based on the author's learning and teaching experience, this paper firstly analyzed the problems in the financial teaching in the Internet finance era and then proposed the construction thought of applied financial discipline system from four modules, including the public quality module, professional basis module, professional core skill module and occupational comprehensiveness and development module.

Keywords: Internet finance; Applied type; Finance major; Discipline system; Construction thought
\end{abstract}

\section{Introduction}

Alipay, WeChat payment and other Internet financial service products make the financial sales model more modern and promote the rapid development of financial industry in the Internet era. Meanwhile, the operation of Internet financial products has brought enormous pressure and challenges to the traditional financial model. It is observed that the Internet finance has become an inevitable trend of the development of the times[1]. In this situation, colleges and universities must conform to the development of the times and take targeted measures and methods to carry out in-depth financial teaching practice reform. 
Only in this way, can colleges cultivate talents with higher comprehensive qualities and excellent practical ability, so as to meet the requirements of the future development of financial enterprises.

\section{Problems in the Financial Teaching in the Internet Finance Era}

\subsection{The use of traditional personnel training model}

The traditional training objective of the finance major in colleges and universities is relatively simple. The positions that students can choose include bank counter workers, securities investors and insurance or fund salesmen. At the same time, with the rapid development of Internet finance, the employment field has been broadened and there appear more new positions. In particular, the appearance of Yu'E Bao, Wechat Bank and other financial business models breaks the basic operation model of traditional banks and brings new opportunities for the development of financial industry[2]. However, many colleges and universities still adopt the traditional teaching objective in financial professional teaching, which limits students' development to a large extent, so that students are facing great employment pressure.

\subsection{The classification of the major is small and students' goal is unclear}

College financial major is generally divided into multiple levels, such as the international finance and financial practice. The goal of international finance is to train top-class financial professionals in finance, which is a high-end development direction. Financial practice is to train front-line staff, such as investment, insurance and financial management. However, due to the similarity in the finance industry, the content of many courses always overlaps. The proportion of the similar content is even more than $85 \%$. At the same time, in addition to the similarity in teaching materials, the use of the same teachers and teaching methods will lead to confusion in teaching objectives, so that students do not have clear direction in the teaching, which will ultimately weaken the development of finance majors.

\subsection{The curriculum lacks innovation and students are not interested in it}

At this stage, the financial curriculum is still in the traditional model and the main directions contain financial management and financial practice. Specific courses include economic management knowledge, accounting practice, basic computer knowledge, securities investment, financial management, risk management and bank counter business[3]. It can be perceived that these courses aim at developing students' financial business capacity, which is the traditional training objective. However, there is no new knowledge or theory of financial development in these courses, not alone the knowledge of the Internet finance. In this case, students 
lose interest in finance and confidence in the future work. Some students even spend a lot of time to take the accounting qualification certificate exam with the consideration of changing their jobs .

\subsection{The teaching methods are backward and outdated}

Teaching methods are generally divided into two types in colleges and universities. On one hand, they use the traditional cramming method. Teachers teach something and students take notes in class. On the other hand, teachers simply explain the text and then assign teaching tasks. These two kinds of teaching methods take the teacher as the leading role and neglect students' individuality. Students' dominant role can not be reflected in the class, which reduces their enthusiasm to participate in the courses and leads to low teaching efficiency[4]. With the continuous development of Internet finance, the social demand for students' practical and innovative ability is gradually improved. In this situation, the use of traditional teaching model clearly hampers students' development, which cannot meet the requirements of the future development of Internet finance.

\subsection{Teaching evaluation method is single and cannot reflect the actual level}

Most colleges and universities use the same evaluation methods and standards to assess students, which is just a simple addition of students' final score and regular grade. This assessment method is too single and mechanical, which can not evaluate students' actual operational capacity, so there exists a big limitation. As time passes, it is not conducive to the cultivation of students' practical ability and will result in that a majority of college students lack practical experience after graduation and encounter difficulties in solving specific problems. Internet finance industry needs high-end practical talents, so such evaluation standards are obviously very backward and can not meet development requirements of enterprises.

\section{The Construction Thought of Applied Financial Discipline System in the Internet Finance Era}

\subsection{Public quality module}

Courses of public quality module: entrance education and military training, military theory, ideological and moral cultivation and basic law education, introduction to Maoism and theoretical system of socialism with Chinese characteristics, situation and policy, advanced mathematics, information technology instruction, intensive training of information technology examination, college English, sports,college students' career development and employment entrepreneurship guidance and college students' entrepreneurship and training. Entrance education and military training and intensive training of information 
technology examination have 2 credits respectively; situation and policy, students' career development and employment entrepreneurship guidance and college students' entrepreneurship and training hold 1 credit respectively; college English and sports occupy seven credits respectively; ideological and moral cultivation and basic law education, advanced mathematics and information technology instruction hold 3 credits; military theory is 1.5 credits; introduction to Maoism and theoretical system of socialism with Chinese characteristics is 4 credits. The total is 35.5 credits [5].

\subsection{Professional basis module}

The courses of professional basis module are designed to guide and nurture students' financial professional qualities and provide students with a window to study how domestic and foreign economic development, financial development, social development and laws or regulations influence human behavior. Besides, these courses explain how to reach a collaborative relationship between these knowledge fields to form financial institutions extensively from the perspective of national macroeconomics or microcosmic financial policy. The broad knowledge and experience can help students to integrate knowledge in different fields to better understand the content and changes in Internet finance and finally help them establish the perception of the finance industry, so as to lay a solid foundation for the follow-up learning of professional skills. There are seven basic courses in professional core skill module: western economics, financial management, accounting, financial law, financial English, currency banking and financial management practice. All courses are 3 credits respectively and the total is 21 credits. New courses in Internet finance era: introduction of network finance ( 2 credits, to make students know the development of Internet finance) and sales of financial products ( 2 credits, to deepen students' understanding of the basic knowledge of finance and improve their practical ability). This adds 4 credits in the module[6].

\subsection{Professional core skill module}

The fundamental courses of professional core skill module: bank accounting, commercial bank management, international finance, securities investment analysis, insurance principles and practice and financial product marketing (integration of teaching and learning). All courses are 3 credits and the total is 18 credits. 4 new targeted courses in the Internet finance: (1) Electronic payment and network finance: according to the development of third-party network payment, the course uses online banking, e-payment, financial network and other Internet technology to make students know basic operation of network bank, payment and balance by virtue of practice, so that they can improve their ability to adapt to the development of Internet finance. It has 3 credits. (2) Financial risk management: students can understand the risk in financial service with the study of the course to lower the risk by financial management. It holds 2 credits. (3) Simulated training of banking business. Students can understand the banking business operation in the course. It has 2 credits. (4) Network payment and balance 
training. According to the purpose and task of e-payment, students can use network resources to take practice and learn system simulation software. This will enable them to apply theoretical knowledge to practice. They can have a comprehensive understanding of networks and e-banking and master the network payment and balance skills. The course is 2 credits.

\subsection{Occupational comprehensiveness and development module}

The courses in occupational comprehensiveness and development module include basic courses and additional courses. The basic courses: statistics, financial basic skill training, graduation practice, graduation design and internship. Statistics holds 3 credits; financial basic skill training is 3 credits; graduation practice occupies 8 credits; graduation design is 10 credits and the internship has 18 credits. The total is 42 credits. In the Internet financial environment, the new course is the database. In the era of IT big data, each industry and business depends on data information. The study of large databases can help students learn more financial business information. The database courses has 2 credits[7].

With the statistics of the credits of the above courses, it is concluded that the total credits of all the courses of the finance major in colleges and universities are 131.5 credits. The basic quality module has 35.5 credits; professional basis module has 21 credits; professional core skill module holds 18 credits; occupational comprehensiveness and development module is 42 credits; additional related courses has 15 credits. Students can graduate successfully with gaining all credits in the four modules.

\section{Conclusion}

The construction of financial discipline system in Internet finance era aims at meeting the talent demand of financial development. College teaching is an important force in social development and the development of finance major in colleges and universities and it has great significance for the improvement of college financial system. Therefore, it is necessary to constantly strengthen the reform of teaching content and model of the finance major in colleges and universities. Schools should change the previous development model and establish college education system in line with the needs of social development, so as to conform to the development of the society, cultivate qualified talents for the society and promote the development and improvement of social construction.

\section{References}

[1] Mao Jinfen, Ling Jianyu. A Study on the Construction of Financial Curriculum System in Higher Vocational Colleges in the Internet Finance Environment. Journal of Wuxi Vocational and Technical College, 2015,06: 76-79 +90 . 
[2] Ma Jingjing, Duan Zongzhi. A Research on the Teaching Reform of Financial Courses of Financial Management. Higher Education Forum, 2008,04: 145-147.

[3] Tang Wenbo. A Discussion on the Construction of Financial Curriculum System in Higher Vocational Colleges. Business Economy, 2009,03: 116-117 +124 .

[4] Yin Huibin, Wang Huaqiu. A Research on Experimental Teaching Curriculum System of the Finance Major. Journal of Hunan Finance and Economic College, 2006,05: 116-118.

[5] Fang Rongjun. A Discussion on the Reform of Curriculum System and Teaching Content of the Finance Major in Universities and Colleges. Journal of Chizhou Teachers College, 2003,06: 112-113.

[6] Gu Zheng, Wang Jiahua. A Discussion on the Construction of Financial Experimental Curriculum System. Research on Laboratory Work in Colleges and Universities, 2014,01: 78-80.

[7] Chen Zhu. A Discussion on the Construction of Financial Experimental Curriculum System. Modern Computer (Professional Edition), 2014,22: 3-5. Index, 2010, 08: 97-98+ 139 . 